\title{
Elements of a Community of Learners in a Middle School Science Classroom
}

\author{
BARBARA A. CRAWFORD \\ Department of Curriculum and Instruction, 171 Chambers Building, or College of \\ Education, The Pennsylvania State University, University Park, PA 16802, USA \\ JOSEPH S. KRAJCIK, RONALD W. MARX \\ Department of Educational Studies, The University of Michigan, Ann Arbor, MI, USA
}

Received 28 April 1997; revised 11 September 1998; accepted 5 October 1998

\begin{abstract}
The idea of a learning community has gained attention as a desirable environment that could provide opportunities for students to engage in solving problems in collaboration with peers. However, definitions of a community of learners are varied, vague, and not well-developed. The goal of the research described in this study is to examine the nature of a middle school science classroom during the development of a community of learners by focusing on the teacher-student interactions and the connections made by students with people outside the classroom. The first investigator served as both teacher and researcher in this study. The teacher used a project-based approach that allowed learners to find solutions to authentic problems or questions generated by the students. Students used a process of inquiry and collaboration to find these solutions. An analytical framework developed from the literature consisted of the following components: authentic tasks; interdependency in small group work; negotiation of understanding; public sharing; collaboration with experts; and responsibility for shared learning and teaching. The framework was used to analyze the multiple data sources, including videotapes, interviews, a teacher's journal, and electronic correspondence. Eight major themes emerged from the analysis. These themes included: (1) tasks connected to real-world questions generated more collaborative interactions than topic-bound tasks; (2) collaborative interactions in groups increased when tasks were student-initiated; (3) providing instructional support for students contributed to group decision making; (4) group productivity increased when students gained ownership; (5) student dialogue centered on the procedural aspects of the activity when completing teacher-designed activities; (6) when public sharing centered on discussions of their own experiences, students were more cognitively engaged; (7) interactions with outside resource people increased students' investment in the project; and (8) when students worked in teams answering their own questions, they took responsibility for learning and teaching. The findings of this study point to three important factors that influenced the learning community in this middle school classroom: (1) the importance of the driving question in contributing to the authentic nature of the investigations; (2) the importance of the teacher's role in supporting students in collaborating with peers and
\end{abstract}

Correspondence to: B. A. Crawford; e-mail: bac21@psu.edu 
people outside the classroom; and (3) the extended time required for teams to develop collaborative relationships. The role of the teacher appears critical in transforming the roles of students and teacher in creating a community of learners. (C) 1999 John Wiley \& Sons, Inc. Sci Ed 83:701-723, 1999.

\section{INTRODUCTION}

National calls for improving science education (AAAS, 1993; NRC, 1996) suggest changes in science classrooms that include situating instruction in a context, facilitating learners to share ideas and information, and encouraging students to explore questions in order to develop in-depth understandings of science content and processes. One approach for accomplishing these goals is to change classroom settings so that learning is more collaborative, thereby helping students to engage more thoughtfully in activities as they work with peers (Krajcik, Blumenfeld, Marx, \& Soloway, 1994). Collaboration in such learning communities involves students in negotiating ideas, distributing knowledge, and gaining social responsibility (Brown, Collins, \& Duguid, 1989; Lave \& Wenger, 1991; Rogoff, 1990).

The idea of a learning community has gained attention as a desirable environment that could provide opportunities for students to engage in solving problems in collaboration with peers. However, definitions of a community of learners are varied, vague, and not well-developed. Research has shown that this kind of instruction is rare in today's classrooms (Gallagher, 1989), difficult to carry out, and requires teachers and students to change roles and responsibilities (Rogoff, 1994). Examples of learning communities can be found in mathematics classrooms (Lampert, 1990; Wilcox, Schram, Lappan, \& Lanier, 1991) and in inquiry-based environments in science classrooms (Marx et al., 1994; Roth, 1994; Scott, 1994). However, the essential elements of a community of learners requires further elaboration.

The goal of the research described in this study is to examine the nature of a middle school science classroom during the development of a community of learners by focusing on the teacher-student interactions and the connections made by students with people outside the classroom. An important outcome of this study is to document the importance of theoretical dimensions of a community of learners in the rough and tumble of practice, rendering the findings relevant to teachers and researchers.

\section{Theoretical Background}

Constructivist perspectives of learning and teaching advocate teachers fostering learning by engaging students in building and restructuring explanations of the world around them (Driver, Asoko, Leach, Mortimer, \& Scott, 1994). This principle of active construction puts emphasis on the student, and proposes that the learner actively constructs knowledge by building on previous understandings. Social constructivists advocate that, through discourse and conversations situated in meaningful contexts, students construct new knowledge through negotiation of their ideas (Collins, Brown, \& Newman, 1989). Much research in the area of collaboration builds on Vygotsky's (1978) view that knowledge is collaboratively constructed from interacting with others. Learners have a range of abilities and a teacher can stretch the students' capabilities by interacting in the outer boundaries of their learning zone. Vygotsky identifies this cognitive space as the zone of proximal development. Paralleling this social constructivist perspective, collaboration in classrooms involves sharing tasks and exchanging and critiquing ideas for the purpose of building new knowledge (Magnusson \& Palincsar, 1995). 
Drawing from the literature related to collaborative learning, we identified six components (see Table 1) of a community of learners: (1) instruction is situated in authentic tasks; (2) students develop interdependency in small group work; (3) students and teacher debate ideas and negotiate understanding; (4) students and teacher publicly share ideas with members of the classroom community; (5) students collaborate with experts outside the classroom; and (6) responsibility for learning and teaching is shared.

Authentic tasks. Various researchers refer to authenticity in slightly different ways. For example, Brown et al. (1989) used the term "authentic" to relate to the ordinary activities of practitioners. Roth (1995), in the preface to his work titled Authentic School Science, defined "authentic" as student work that relates to five aspects of the work of scientists. These five aspects include ill-defined problems, ambiguous and social nature, driven by the learner's knowledge state, shared discourse, and access to knowledge of others. Yet a third slant to the term "authentic" is used by Dewey in his advocating learning based in real-world projects. In this study, authentic instruction involves creating environments similar to those of practitioners (Resnick, 1987) and related to students' own interests. In the case of the science classroom, authentic instruction engages students in pursuing answers to significant questions that are relevant to students and similar to activities of professional scientists (Brown et al., 1989). Solving problems and doing "real" science in the classroom stems from Dewey (1938) who argued that the school community is a place where a child gains authentic experiences by doing projects rather than solving isolated problems. For example, in designing authentic instruction that addresses science concepts such as Newton's laws, teachers could engage students in exploring such problems as

TABLE 1

Components of a Community of Learners in a Science Classroom

\begin{tabular}{lcc}
\hline \multicolumn{1}{c}{ Component } & \multicolumn{1}{c}{ Description } & \multicolumn{1}{c}{ Literature Base } \\
\hline Authentic tasks & Instruction is situated in & Brown et al., 1989; Dewey, \\
& tasks that are based on & 1938; Duschl \& Gitomer, \\
& real-world problems & 1993; Lave, 1988; Res- \\
nick, 1987; Roth, 1994 & Bruffee, 1993; Cohen, 1986; \\
Interdependency in small- & Group members function by & Collins et al., 1989; \\
group work & relying on each other to & Sharan \& Hertz-Lazarow- \\
& complete a task & itz, 1980; Slavin, 1981; \\
& & Wilcox et al., 1991 \\
Negotiation of under- & Students and teacher de- & Lampert, 1990; Linn \& Bur- \\
standing & bate ideas and negotiate & bules, 1993; Vygotsky, \\
& understanding of substan- & $1978 ;$ Wood, Cobb, \& \\
tive science content & Yackel, 1992 \\
Public sharing & Students and teacher pub- & Duschl \& Gitomer, 1993; \\
& licly share ideas with & Lampert, 1990; Smith, \\
& members of the class- & 1991 \\
Collaboration with experts & Students collaborate with & Roup et al., 1993; Warren, \\
& experts outside the class- & Rosebery, \& Conant, \\
& room community & 1989 \\
Shared responsibility & Responsibility for learning & Brown \& Campione, 1990; \\
& and teaching is shared & Rogoff, 1994; Newman et \\
& & al., 1989; Schwab, 1976; \\
& & Wilcox et al., 1991 \\
\hline & &
\end{tabular}


"How Can You Ride on a Skateboard?" or "What Happens When You Ride on a Roller Coaster?" Through exploring these kinds of questions, students can build connections between abstract science concepts and real-world applications. ${ }^{1}$

Interdependency in small group work. Cohen (1986) addressed the importance of having group members acquire interdependency. Although group members may struggle at times, teachers should delegate authority to group members to communicate and depend on each other. As distinguished from collaboration, group learning is often equated with cooperative learning (Johnson \& Johnson, 1991; Slavin, 1981), which involves rules used by teachers for distributing group tasks. Aspects of collaborative learning may appear to overlap with those of cooperative learning. In collaborative learning, students focus on sharing and debating ideas versus cooperatively completing a definite task. This interdependency is facilitated by shifting the control from the teacher to the students working collaboratively (Bruffee, 1993).

Negotiation of understanding. In a community of learners all participants in the classroom collaborate in a social context, negotiating meanings and distributing expertise while solving authentic problems. Studies of classrooms in which students engage in collaborative interactions depict teachers as collaborators in developing in-depth understandings of important concepts (Linn \& Burbules, 1993; Wood, Cobb, \& Yackel, 1992). In order for students to negotiate shared meanings, they have to approach a common meaning in a learning zone where the minds of participants meet (Newman et al., 1989).

Public display. Smith (1991) describes a model of a learning community where students develop scientific understandings collectively. In this learning environment students make their understandings public in order to explore their ideas and modify these understandings toward a more scientific point of view. In mathematics classrooms members of communities of learners participate in public discourse as the teacher and other students explain their own understandings and critique other members' ideas. Through a collaborative process, children discuss, reflect upon, evaluate, and validate each others' understandings in concert with the teacher (Lampert, 1990; Wood et al., 1992).

Collaboration with experts. Opportunities to collaborate with experts may come from personal connections with people in the local community or from teachers extending the walls of their classrooms using telecommunications (Roup, Gal, Drayton, \& Pfister, 1993). Development of scientific discussions in a learning community may emerge from the teacher guiding the students in a cognitive apprenticeship (Collins et al., 1989). Engagement of students in social interactions with outside experts simulates an apprentice/master craftsman relationship.

Shared responsibility for learning and teaching. In a community of learners all members - students and teachers - actively engage in both learning and teaching (Rogoff, 1994). This aspect of a community of learners involves a transformation of participation in which the roles of the members in the classroom change with the change in sociocultural activities (Newman et al., 1989; Rogoff, 1994). The interchange of roles in a learning environment contrasts with models of a teacher-run (dispenser of knowledge) and student-run (discovery) orientation to the instruction. A community of learners is a dynamic, changing, learning space in which the students and teacher are equally important participants, whose roles change over the course of the project as different expertise comes into play.

\section{Pedagogical Framework}

As a setting in which to build a collaborative environment, the instruction described in this study was patterned after project-based science (Krajcik, Blumenfeld, Marx, \& So-

\footnotetext{
${ }^{1}$ In this study, the term "real world" refers to the world beyond the classroom.
} 
loway, 1994; Roup et al., 1993). Within the framework of project-based science students strive to solve realistic problems by asking questions, debating ideas, collecting and analyzing data, finding patterns, drawing conclusions, and creating artifacts representing their understandings (Blumenfeld et al., 1991).

In project-based science, an encompassing driving question is selected by the teacher in order to organize the subquestions, which are student-generated. This organizing question should be meaningful to the students, involve important science content, and be large enough to allow the spawning of student-initiated questions related to the driving question (Krajcik et al., 1994). The project-based science model promotes instruction over an extended period, providing a context for developing a community of learners.

Various researchers report on different aspects of collaboration: development of social skills and the establishment of group norms (Linn \& Burbules, 1993; McCaslin et al., 1994; Solomon, 1989); designing investigations and developing process skills (Duschl \& Gitomer, 1993; Linn \& Songer, 1992; Roth \& Roychoudhury, 1993a, 1993b); and negotiating meanings (Lampert, 1990; Wood et al., 1992). Few studies have investigated the processes involved in creating a community of learners by extensively examining studentstudent and student-teacher interactions in detail over a substantial period of time. This study helps fill this gap.

\section{METHOD}

Similar to the teacher as researcher models exemplified by Ball (1990), Lampert (1990), and Roth $(1994,1995)$ and following the model of a design experiment (Brown, 1992) this study involved a three-part process: (1) designing an extended course of instruction referred to as a project; (2) teaching the project; and (3) examining what happened in the classroom during the instruction.

\section{Design of the Project}

The project design in this study focused on an authentic problem area: hazardous chemicals in our lives. The driving question that was selected, Are there poisons in our lives?, was intended to be broad and link lessons about chemistry to the lives of both students and teacher. The three main areas of science content addressed properties of matter, properties of acids and bases, and solutions. Having identified the topic of the instruction, the overall driving question, and the specific science concepts to be addressed, attention was placed on embedding key lessons called benchmark lessons. These benchmark lessons in the form of lab activities or class discussion were designed to build students' background knowledge as they explored the driving question. Planned sites where students could collaborate in small and large group settings were integrated in the project design in order to foster a community of learners. Detailed descriptions of the 12-week project that was taught in the spring can be found in Crawford (1996).

\section{Context of the Study}

This study focuses on one of four physical science, eighth grade science classes taught by the first author in the 1993-1994 academic year. In this school teachers followed their seventh grade classes into the eighth grade. Therefore, at the time of this study, the teacher had known most of the students for almost 2 years. Crawford (referred to as "the teacher") holds degrees in microbiology and biology and worked as a research microbiologist and chemical engineer before teaching middle school. At the time of this study she had taught full time in this middle school for 6 years and in the school district for 16 years. The 
school is situated in a relatively affluent midwestern university town of about 110,000 people. The 26 students in the classroom, including two special needs students, represented a wide range of academic achievement and classroom behavior. During the year in which the study took place, the teacher met monthly with a university-based group of teachers and researchers to discuss the challenges related to project-based science instruction. Other than this support, her role as a public school teacher involved the typical full range of challenging responsibilities: contacting parents; conducting after-school activities; counseling students in selecting high school courses; mediating disagreements and feuds between students; serving on faculty and district committees; chaperoning school functions; and doing cafeteria and hall duty.

\section{Participants}

The class selected for the study was the first of four science classes taught daily. Selection of this class permitted an assistant the opportunity to set up the video camera before the students arrived. Often the videotaper informally interviewed the teacher about her objectives before class started, creating an informal video journal. The students (14 boys, 12 girls) generally sat at tables in heterogeneous teams of three or four students. There were seven teams and for the most part, the students remained in these teams for the duration of the 12-week project.

One of the seven teams served as a focus team to permit detailed observations of student-student interactions. The four students in this team were randomly selected from students in the class who had previously received C's, B's, or low A's during the first semester, leaving out the high and low extremes. This decision was based on the assumption that these students may be more likely to change than top students or students having problems with school in general. Characteristics of the two girls, Tammy and Eileen, and the two boys, Bobby and Nathan, appear in Table 2. (Names of students are pseudonyms.)

Tammy, who was animated, energetic, and verbally outgoing, sometimes to the point of being outspoken, was generally a good student and had a twin brother who was in the seventh period science class. Eileen was quieter than Tammy and not as outgoing around adults. Sometimes she handed in assignments late due to frequent absences and she often complained about other classes, teachers, and homework. Bobby was bright, witty, and interested in computers. His mother had noted at a parent-teacher conference that he had not been working up to his potential in school. Bobby, who had told his mother that the eighth grade did not count anyway, projected an attitude that school was not as important as his after-school clubs. Nathan was very quiet and rarely volunteered to participate in whole class discussions. He often appeared disinterested or tired during the class period,

\section{TABLE 2}

\section{Characteristics of Students in the Focus Team}

\begin{tabular}{lccllllc}
\hline Name & Gender & Age & $\begin{array}{c}\text { Mirth } \\
\text { Month }\end{array}$ & \multicolumn{1}{c}{ Ethnicity } & $\begin{array}{c}\text { MEAPa } \\
\text { Science }\end{array}$ & $\begin{array}{c}\text { CAT }^{\mathrm{b}} \\
\text { Math }\end{array}$ & $\begin{array}{c}\text { CAT }^{\mathrm{b}} \\
\text { Reading }\end{array}$ \\
\hline Tammy & F & 13 & October & Caucasian & $28 / 31$ & $98 \%$ & $81 \%$ \\
Eileen & F & 13 & September & Caucasian & $19 / 31$ & $95 \%$ & $68 \%$ \\
Bobby & M & 14 & February & Caucasian & $28 / 31$ & $98 \%$ & $97 \%$ \\
Nathan & M & 13 & November & African American & $13 / 31$ & $56 \%$ & $28 \%$ \\
\hline
\end{tabular}

aMichigan Educational Assessment Program Test. Indicates number of objectives passed.

${ }^{\mathrm{b}}$ California Achievement Test 1994. Indicates percentile compared with national average. 
sometimes putting his head down on the table during discussions. Nathan did not always hand in his homework. However, just prior to this poisons project, Nathan had completed an extra credit science project on musical instruments with support from his father.

\section{Data Sources and Analytical Framework}

The main source of data used in this study was the set of 25 videotapes of lessons that provided critical information on the interactions that occurred in the classroom and how these interactions changed over time. Additional data sources included the teacher's wordprocessed journal notes and her reflections that were tape-recorded shortly after instruction. Videotaped interviews of the focus team and an e-mail log contributed additional information. These data sources were analyzed to answer the overall question: "What essential elements emerged in the classroom related to developing a community of learners?"

In order to determine the roles played by the six elements of a community of learners in this classroom, the framework developed from the literature was used to focus the analysis. This framework served to organize the data and to identify patterns that deveoped during instruction (Yin, 1989). For each of the six elements, a range of descriptions from traditional to intermediate to constructivist determined characteristics in the classroom. The continua used to analyze the nature of the interactions is shown in Tables 3-8.

\section{Data Analysis}

Analysis of the data followed a three-part scheme consisting of data reduction, data display, and conclusion drawing and verification (Miles \& Huberman, 1994). The data reduction phase itself continued throughout the entire analysis process following a narra-

\section{TABLE 3}

\section{Characteristics of Authentic Tasks: What Is the Nature of the Task?}

Type of

Environment Characterization Example

\begin{tabular}{|c|c|c|}
\hline Traditional & $\begin{array}{l}\text { Instruction is situated in topic ar- } \\
\text { eas and aligned with textbook } \\
\text { chapters; students learn by per- } \\
\text { forming prescribed exercises }\end{array}$ & $\begin{array}{l}\text { Students complete a worksheet } \\
\text { by giving definitions for New- } \\
\text { ton's three laws as worded in } \\
\text { the textbook }\end{array}$ \\
\hline Intermediate & $\begin{array}{l}\text { Instruction may be relevant to stu- } \\
\text { dents' lives; however, tasks are } \\
\text { determined mainly by the } \\
\text { teacher }\end{array}$ & $\begin{array}{l}\text { Students bring skateboards to } \\
\text { school; students carry out in- } \\
\text { vestigations outlined by the } \\
\text { teacher which relate to New- } \\
\text { ton's second law and how it af- } \\
\text { fects riding on a skateboard }\end{array}$ \\
\hline Constructivist & $\begin{array}{l}\text { Instruction is anchored in stu- } \\
\text { dents' lives and situated in real- } \\
\text { world contexts; students take } \\
\text { ownership of the problem area, } \\
\text { and formulate their own ques- } \\
\text { tions }\end{array}$ & $\begin{array}{l}\text { Students ask and refine their own } \\
\text { questions relating to force and } \\
\text { motion, and carry out their own } \\
\text { investigations relating to New- } \\
\text { ton's second law, such as how } \\
\text { it pertains to riding on a skate- } \\
\text { board, riding a bicycle, or riding } \\
\text { on a roller coaster }\end{array}$ \\
\hline
\end{tabular}




\section{TABLE 4}

Characteristics of Interdependency in Group Work: What Is the Nature of the Small Group Work?

\begin{tabular}{|c|c|c|}
\hline $\begin{array}{c}\text { Type of } \\
\text { Environment }\end{array}$ & Characterization & Example \\
\hline Traditional & $\begin{array}{l}\text { Students are guided maximally by } \\
\text { directions given by the teacher } \\
\text { for the small group work; in- } \\
\text { struction is mainly procedural }\end{array}$ & $\begin{array}{l}\text { Students do a laboratory activity } \\
\text { using pH paper to test three } \\
\text { solutions following directions } \\
\text { given by the teacher: Teacher } \\
\text { goes over all directions care- } \\
\text { fully: Label one cup "cup A," } \\
\text { another cup, "cup B". . . }\end{array}$ \\
\hline Intermediate & $\begin{array}{l}\text { Students work in groups, but they } \\
\text { ask the teacher frequently for } \\
\text { direction during their group dis- } \\
\text { cussion }\end{array}$ & $\begin{array}{l}\text { Students work in groups discuss- } \\
\text { ing the design of an investiga- } \\
\text { tion of acids and bases in their } \\
\text { homes. The teacher constantly } \\
\text { circulates through the room, } \\
\text { stopping often to tell the stu- } \\
\text { dents how to structure the in- } \\
\text { vestigation }\end{array}$ \\
\hline Constructivist & $\begin{array}{l}\text { Students help determine the direc- } \\
\text { tion of their investigation; stu- } \\
\text { dents look to group members } \\
\text { instead of mainly to the teacher } \\
\text { for ideas }\end{array}$ & $\begin{array}{l}\text { After brainstorming in their group, } \\
\text { students choose to investigate } \\
\text { acids and bases in their } \\
\text { homes. They independently } \\
\text { decide among themselves } \\
\text { which household substances to } \\
\text { test, how to design the investi- } \\
\text { gation, and how to carry it out }\end{array}$ \\
\hline
\end{tabular}

tive method developed by Krajcik et al. (1994). In this narrative method, videotapes, the bulk of the data source, were analyzed by first writing narrative descriptions of lesson segments. A segment was defined as a change in activity or focus during the lesson. Following the narrative description of each segment, a summary highlighted key events. This summary was followed by a commentary that used the analytical framework derived from the literature. This commentary identified the elements of a community of learners evident in the lesson. For example, during one lesson segment students brought in news articles on chemicals in the environment. This event was labeled as an authentic task, intermediate between traditional and constructivist, because the instruction may have been relevant to students' lives, yet the task was determined mainly by the teacher. Evidence of students and teacher engaging in collaborative events or conversations were noted, and these sections were transcribed. Finally, hypotheses were written for each event that related to the analytical framework. This process produced a narrative document for each videotaped lesson (see Crawford, 1996).

Additional data sources were used to triangulate the data. The journal chronicled the teacher's rationale for various pedagogical decisions and reflections on what transpired in the classroom. Transcriptions of these journal entries were used to add richness to the emerging picture of the classroom environment and to support or refute hypotheses that were generated as the videotaped lessons were analyzed. Transcriptions of the student interviews further triangulated the data, creating an image of the classroom environment 
TABLE 5

Characteristics of Negotiation of Understanding: What Is the Nature of the Dialogue in the Groups?

\begin{tabular}{|c|c|c|}
\hline $\begin{array}{c}\text { Type of } \\
\text { Environment }\end{array}$ & Characterization & Example \\
\hline Traditional & $\begin{array}{l}\text { Students do not ask unsolicited } \\
\text { questions; teacher tells students } \\
\text { his/her interpretations; dialog re- } \\
\text { lated to procedures of the task/ } \\
\text { lab activity; students appear } \\
\text { passive during the lesson }\end{array}$ & $\begin{array}{l}\text { Students discuss the correct pro- } \\
\text { cedure for using pH paper and } \\
\text { how to label the cups in testing } \\
\text { the acidity of some solutions; } \\
\text { students concerned mainly } \\
\text { with completing the task }\end{array}$ \\
\hline Intermediate & $\begin{array}{l}\text { Students initiate discussion of } \\
\text { ideas of science concepts or } \\
\text { processes }\end{array}$ & $\begin{array}{l}\text { Students brainstorm ideas of ac- } \\
\text { ids and bases that may be } \\
\text { hazardous to humans, individu } \\
\text { ally giving ideas, but do not } \\
\text { sustain a discussion }\end{array}$ \\
\hline Constructivist & $\begin{array}{l}\text { Students actively participate dur- } \\
\text { ing the lesson; students discuss } \\
\text { ideas with others; teacher and } \\
\text { students generate interpreta- } \\
\text { tions collaboratively; student } \\
\text { discourse is related to debating } \\
\text { ideas within small groups ver- } \\
\text { sus procedural or off-task talk }\end{array}$ & $\begin{array}{l}\text { Students discuss how to best set } \\
\text { up an investigation to deter- } \\
\text { mine the effect of acidity on } \\
\text { plant growth; students debate } \\
\text { how many plants to use, what } \\
\text { acidic solutions to use, how to } \\
\text { measure the growth, and how } \\
\text { to make sense of the data }\end{array}$ \\
\hline
\end{tabular}

from multiple perspectives: the actions of the students and teacher during instruction; the reflections of the teacher; and the reflections of the students.

Following the data analyses, attention was directed to finding patterns that emerged across the lessons. Matrices were used (Miles \& Huberman, 1994) for data display to show the nature of the classroom events over time. All three authors collaborated on the process of data reduction and analyses used in interpreting the videotapes and other data that contributed to final emergence of themes and tentative conclusions.

\section{RESULTS}

During the course of the poisons project students engaged in collaborative interactions during a number of key instructional events: discussions of environmental issues in wholeclass settings; brainstorming ideas for team studies of potentially hazardous substances; sharing ideas of experimental designs; exchanging information from the media center; working personally with experts in the community; using telecommunications to contact experts outside the school community; working interdependently in teams to conduct student-designed investigations; and publicly sharing the team findings of each poison study with the class.

The project had four divisions created by the following three important events: (1) the introduction of the driving question, Are there poisons in our lives?, which appeared to give students a purpose for subsequent classroom discussions and activities; (2) the final selection by each team of their team poison, ${ }^{2}$ which focused the students on retrieving

\footnotetext{
${ }^{2}$ The term "team poison" refers to the substance that each team chose to investigate.
} 
TABLE 6

Characteristics of Public Sharing: What Is the Nature of the Reporting of Ideas?

\begin{tabular}{|c|c|c|}
\hline $\begin{array}{c}\text { Type of } \\
\text { Environment }\end{array}$ & Characterization & Example \\
\hline Traditional & $\begin{array}{l}\text { Students receive science knowl- } \\
\text { edge as a well defined body of } \\
\text { information from the teacher } \\
\text { who is the main transmitter of } \\
\text { information in whole class } \\
\text { format }\end{array}$ & $\begin{array}{l}\text { Students listen to teacher lectur- } \\
\text { ing on definitions of atoms, } \\
\text { molecules, and compounds; } \\
\text { students privately discuss un- } \\
\text { derstandings }\end{array}$ \\
\hline Intermediate & $\begin{array}{l}\text { Students report to others in the } \\
\text { class information found in text- } \\
\text { books and encyclopedic source }\end{array}$ & $\begin{array}{l}\text { Students report to the class infor- } \\
\text { mation gained mainly from the } \\
\text { textbook about the chemical } \\
\text { composition of plant fertilizers, } \\
\text { and its health effects on hu- } \\
\text { mans }\end{array}$ \\
\hline Constructivist & $\begin{array}{l}\text { Students share their own ideas } \\
\text { publicly with other members of } \\
\text { the class for feedback and } \\
\text { revision }\end{array}$ & $\begin{array}{l}\text { Students publicly share ideas of } \\
\text { setting up an investigation of } \\
\text { the effect of plant fertilizers, on } \\
\text { plant growth; other students in } \\
\text { the class question the experi- } \\
\text { mental design, and suggest a } \\
\text { better, and safer, means of } \\
\text { setting up the investigation }\end{array}$ \\
\hline
\end{tabular}

TABLE 7

Characteristics of Collaboration with Experts: What Is the Nature of Collaborating with Experts?

\begin{tabular}{|c|c|c|}
\hline $\begin{array}{c}\text { Type of } \\
\text { Environment }\end{array}$ & Characterization & Example \\
\hline Traditional & $\begin{array}{l}\text { Students look to the teacher and } \\
\text { textbook or encyclopedia as the } \\
\text { main sources of information in } \\
\text { the classroom }\end{array}$ & $\begin{array}{l}\text { Students look up smoking and } \\
\text { cigarettes in the library using } \\
\text { the World Book, and then write } \\
\text { up a report }\end{array}$ \\
\hline Intermediate & $\begin{array}{l}\text { Students seek help and gain infor- } \\
\text { mation from experts outside the } \\
\text { classroom from personal con- } \\
\text { tacts or on-line networking }\end{array}$ & $\begin{array}{l}\text { A group of students post an } \\
\text { e-mail message on an elec- } \\
\text { tronic bulletin board asking for } \\
\text { the latest information on car- } \\
\text { cinogens in tobacco; a scientist } \\
\text { sends some recent information } \\
\text { over the network }\end{array}$ \\
\hline Constructivist & $\begin{array}{l}\text { Students exchange ideas with ex- } \\
\text { perts outside the classroom } \\
\text { through personal contacts or } \\
\text { on-line networking }\end{array}$ & $\begin{array}{l}\text { Students exchange ideas with a } \\
\text { scientist on an electronic bulle- } \\
\text { tin board about the latest infor- } \\
\text { mation on carcinogens in } \\
\text { tobacco; students share their } \\
\text { own findings with the scientist, } \\
\text { and exchange ideas }\end{array}$ \\
\hline
\end{tabular}


TABLE 8

Characteristics of Shared Responsibility in Learning and Teaching: What Is the Nature of the Instructional Roles of the Students and Teacher?

\begin{tabular}{|c|c|c|}
\hline $\begin{array}{c}\text { Type of } \\
\text { Environment }\end{array}$ & Characterization & Example \\
\hline Traditional & $\begin{array}{l}\text { Teacher uses directed teaching } \\
\text { such as lecture to present sci- } \\
\text { entific facts and to give informa- } \\
\text { tion; teacher disseminates } \\
\text { knowledge; students watch a } \\
\text { demonstration }\end{array}$ & $\begin{array}{l}\text { Teacher lectures on forms of ni- } \\
\text { trogen and the characteristics } \\
\text { of the element in the periodic } \\
\text { table; students see a video on } \\
\text { chemical properties of nitrogen }\end{array}$ \\
\hline Intermediate & $\begin{array}{l}\text { Teacher takes on the role of } \\
\text { expert and guide leading stu- } \\
\text { dents through a predetermined } \\
\text { path to understanding defined } \\
\text { science concepts and pro- } \\
\text { cesses }\end{array}$ & $\begin{array}{l}\text { Teacher plans a traditional verifi- } \\
\text { cation laboratory to determine } \\
\text { the concentration of nitrates in } \\
\text { several water samples; the } \\
\text { teacher predetermines the cor- } \\
\text { rect values }\end{array}$ \\
\hline Constructivist & $\begin{array}{l}\text { Teacher facilitates the students in } \\
\text { gaining responsibility for their } \\
\text { own learning; teacher and stu- } \\
\text { dents generate interpretations } \\
\text { by working together; students } \\
\text { teach other students and the } \\
\text { teacher }\end{array}$ & $\begin{array}{l}\text { Teacher enables students to col- } \\
\text { lect data on concentrations of } \\
\text { nitrates in the school drinking } \\
\text { water and compare this to ni- } \\
\text { trate levels that are hazardous; } \\
\text { students share their finding } \\
\text { with the class and teacher }\end{array}$ \\
\hline
\end{tabular}

information on their substance; and (3) the teacher handout outlining expectations and timelines for the project, which provided the students with scaffolding to help them structure their investigations and develop their presentations (see Figure 1).

Eight themes, described in detail in what follows, that related to creating a community of learners emerged from the data analysis:

1. Tasks connected to real-world questions generated more collaborative interactions than topic-bound tasks.

2. Collaborative interactions of the group members increased when the tasks were student-initiated.

3. Providing instructional support for students contributed to group decisionmaking.

4. Group productivity increased when students gained ownership.

5. Student dialogue centered on the procedural aspects of the activity when completing teacher-designed activities.

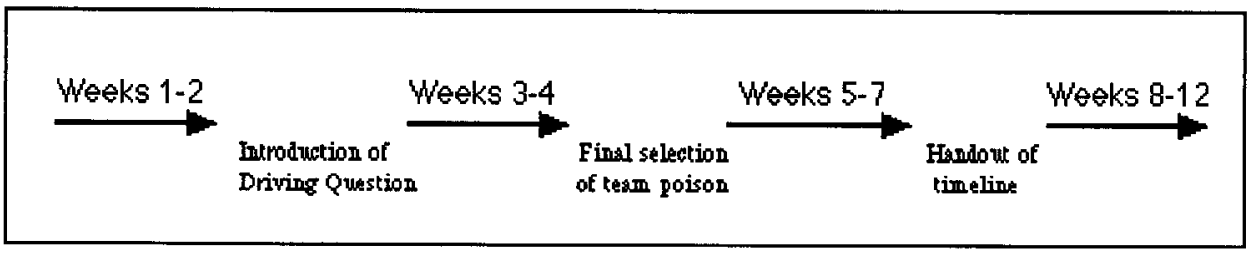

Figure 1. Timeline of the poisons project. 
6. When public sharing centered on discussions of their own experiences, students were more cognitively engaged.

7. Interactions with outside resource people increased students' investment in the project.

8. When students worked in teams answering their own questions, students took responsibility for learning and teaching.

Tasks connected to real-world questions generated more collaborative interactions than topic-bound tasks. As the project developed there was evidence that the nature of the task influenced the level of student collaboration in completing them. In the first week or two, many of the activities appeared to engage students superficially, but careful analysis revealed that the students focused on completing the activity rather than debating ideas and constructing meaningful understandings. Most of the students' involvement in completing these topic-bound tasks were individual efforts, and students appeared motivated primarily by the goal of getting a grade. When tasks changed from a content focus to a connection to real-world problems, the students became more actively engaged in exchanging ideas about how to solve these problems.

One example of an early activity that failed to engage the students in thinking about the science content was a lab in which students mixed and observed a concoction made from cornstarch and water. During this lab the students worked on the mechanical aspects of the task, mixing up the substance, kneading it, poking it, and letting the stuff drip through their fingers. However, most of the students did not engage cognitively in debating the science concepts of physical and chemical changes.

In contrast to this early content-related lesson, the activities that students perceived as authentic $^{3}$ generated thoughtful interactions. During week 3, the teacher introduced the driving question, Are there poisons in our lives? Lessons involving authentic tasks occurred more consistently after the introduction of the driving question. Initially, students brainstormed ideas about potentially hazardous chemical substances. When the teams shared their lists with the class, many of their ideas related to their own lives and to issues that scientists investigate. For example, students listed chlorine relating to the drinking water and the school swimming pool; asbestos relating to a recent school district asbestos abatement program; tobacco and smoking relating to relatives who had suffered from emphysema; and radon, relating to a problem identified recently in neighborhood homes.

The focus team eventually investigated the possibility of vitamin supplements being toxic to humans. The focus team's collaborative activities were designed by themselves. The team centered their investigation on the vitamins that Tammy's dad took each day. The team designed and carried out a controlled experiment using different varieties of plants and different dosages of the variety of vitamins. When the students perceived the task to be authentic, as in determining the toxicity of substances that might affect their health, the level of their engagement increased. Evidence of this increased engagement included initiating their own questions about potentially hazardous substances, volunteering to work on investigations after school, and exchanging ideas about the design of their team experiments.

Collaborative interactions of the group members increased when the tasks were studentinitiated. When the tasks were teacher-controlled and prescriptive, the students focused on the procedural aspects of completing the task. Although they were sitting in teams,

\footnotetext{
${ }^{3}$ The term "authentic" relates to tasks or problems that (1) are similar to what scientists might encounter; and (2) relate to students' lives.
} 
when tasks were teacher-directed the students tended to complete tasks individually and exchanges often were adversarial. In contrast, when the students were involved in the design of the task, and given an opportunity to ask their own questions, interactions in groups became more positive and students exchanged ideas about their own designs.

It took students an extended period to develop positive working relationships in their groups while investigating ideas in their topic area. The focus team did not exhibit consistent positive student-to-student interactions until more than 8 weeks after they had been assigned to work as a team. Undeveloped social skills, tightly directed teacher activities, and lack of ownership in the group work contributed to the dysfunction of some of the groups during the beginning weeks of the project. Criticism of peers and dysfunction of groups has been reported in other studies (Lampert, 1990; Linn \& Songer, 1992; Solomon, 1989). This dysfunction was particularly evident in the focus team during the first half of the project. Bobby, Nathan, Eileen, and Tammy operated during the early part of the project as two girls against two boys, often exchanging derogatory and negative comments while carrying out teacher-designed lab activities.

The beginning of the movement toward more collaboration occurred when the groups began to brainstorm ideas for their own study of a poisonous substance. The movement toward collaboration continued after teams finally decided on a team poison. This involvement was evidenced by group members listening more to each others' ideas than when completing teacher-designed tasks, and taking responsibility for completing the team-designed tasks. The movement toward more collaboration began when the team members were given more opportunity to take part in the decisionmaking.

The change from adversarial to collaborative interactions due to an increase in decisionmaking opportunities can be traced using the focus team. In the case of the focus team, the students became involved in designing their own investigation of the effect of overthe-counter vitamins on plant growth. During the first half of the project the members of the focus team took on adversarial roles when working on lab activities in class. During the midproject interview, the students in the focus team agreed on one thing - their group did not work well together. Nathan referred to their arguing and disagreements. Bobby talked about the rift between the two girls and the two boys. This excerpt from Bobby's interview parallels all the four students' view of their group members:

Um, It's kinda weird. You know me and Nathan, um we just like sit next to each other, and across the table is Tammy and Eileen. It is kinda' divided along those lines. Me and Nathan we like each other. Tammy and Eileen like each other. I don' t like Tammy and Eileen. And they don't like us. We don't work well together.

A typical example of adversarial dialogue occurred during this vignette of a chromatography lab. The activity involved separating the dyes in different colored markers using paper chromatography. Having been assigned roles as head scientist, materials manager, and two investigators, the students focused on making sure they carried out only their own responsibilities. When disagreements arose in the team about procedures, they quickly turned to the teacher as the authority concerning proper procedures.

In contrast to carrying out teacher-designed activities, the focus team interacted more collaboratively when involved in making decisions. An example of the focus team exhibiting interdependence when the task was student-initiated occurred during a group work time in week 8. Tammy had brought in a large plastic bag of vitamins that her dad took each day. While Nathan, Tammy, and Eileen discussed how they might set up an experiment, Bobby worked close by on the computer retrieving e-mail messages. They discussed when they might meet after school as a team to work on the project. Some of the team 
members suggested working at one of their homes on Saturday. Later in the hour, members of the focus team asked the teacher if they could use a section of the school greenhouse for setting up their experiment using plants. A few days after this episode, Tammy brought her team over 30 vegetable plants of four varieties that she had bought at a local greenhouse.

After the focus team had finalized the design of their experiment, the members continued to exhibit interdependence. The students took over part of the greenhouse, cording off a section with masking tape, and writing on the tape in red ink, "PLEASE DO NOT SELL" (relating to an upcoming plant sale by the school greenhouse club). Tammy and Eileen set up a schedule for their team members to take plant measurements during lunch time and after school, and designed a log for recording the data.

One example of collaboration occurred during a team data collecting session. The focus team discovered problems when measuring the growth of the tomato plants. Accurately measuring height was difficult because of the number of terminal leaves, and they were concerned about inconsistent data. Nathan suggested that he bring in his camera as one means of determining change in growth. The other team members agreed that this was a good idea. Eventually, Nathan brought in his camera and took some photos.

Interviews toward the end of the project indicated the changing relationships within the focus team. As in the midproject interview, Bobby focused on the interpersonal aspects of working in a group:

Like people didn't get along very well. And we had trouble getting together. At first we tried to get out of it, and said, it's not going to work, it's not going to work. Ms. C. didn't listen to us. So, we had to work with them . . . So, like it did help to work in a team, because everyone realized that if they didn't do their part, then they would get in trouble with their team. You know, alone, it's like no one is counting on you.

Bobby focused on the commitment to "not let down" the other team members. Bobby admitted that, in the end, working in his team was good, because the group members put pressure on each other to contribute: “. . . everyone realized that if they didn't do their part, then they would get in trouble with their team." By the end of the project the relationship between members of the focus team had changed from one of adversarial roles and dependence on the teacher for external control, to one of cooperation, mutually shared roles, and internal control. Instead of depending mainly on the teacher for direction, team members began to depend on each other for ideas.

Providing instructional support for students contributed to group decisionmaking. Instructional support consists of help provided by the teacher in developing understandings of both science subject matter and science processes. The teacher's instructional support facilitated the students' group decisionmaking. An important decision each team made was to choose the hazardous substance the team would study. The teams in this class eventually chose to investigate these seven substances: radon; asbestos; chlorine in water; food preservatives; vitamins; mercury; and tobacco.

With the wide latitude in the design of their team projects, early in the project the groups struggled with completing their poison studies. Once the students selected their team poison, and obtained initial information, the productivity of the teams stalled. Evidence from the focus team interviews midway through the project suggested that the students' perception of the poison project differed greatly from the teacher's vision. Team members were unclear about how to proceed in the design of their team investigation. As illustrated in Eileen's interview, the students did not have a well-defined idea of how their team would gather data on the effect of vitamins on humans: 
Well, our team poison is vitamins, and we don't have an experiment to do with it, because you see [taking a breath], Bobby picked out vitamins as poisons, and I don't think that it was a good idea, because vitamins usually aren't very poisonous. But I got some information from a magazine that just talked about vitamins. That if you eat too many and whatever, that it's pretty dangerous. So, but we don't have that much information on it.

An example of teacher support that helped the groups design and conduct their investigations consisted of providing explicit guidelines for individual and team products and due dates for final reports. However, there was a delicate balance between guiding team designs and investigations and too much teacher direction, which could reduce student collaboration. For example, the teacher talked with the focus team about the ethics involved in administering vitamins to human subjects as part of their initial design, and responded to their ideas using her knowledge of the science and social constraints.

The increased consensus building during group work due to the role of the teacher as a guide parallels findings in earlier studies in a middle school project-based classroom studying acid rain (Marx et al., 1994). One of the teachers in the Marx and colleagues study reported that her students took more active roles in their groups over time, but "it required considerable direction and intervention on her part" (p. 527).

Group productivity increased when students gained ownership. When students became invested in their own learning, the productivity of the group increased. Evidence of group productivity included teams generating ideas, testing these ideas, and producing artifacts such as lab reports that reflected the group's work. For most of the groups, the team poisons they selected connected in some way to the students' lives. In each team, one student emerged as the leader who took charge of organizing the team and in leading the team to arrive at a consensus.

In the case of the focus team, Tammy expressed concern that her dad took several varieties of vitamins each day. After a class discussion on vitamins in the news during week 4, Tammy had discussed her concern with Eileen. While collaborating with her team during week 9, Tammy announced that she had taken responsibility for bringing in plastic bags of her dad's vitamins for their plant experiment. When the focus team began to design their investigation using these vitamins and began to gather their data, the members demonstrated their increased ownership by volunteering to take turns taking measurements after school and during lunch. In addition to initiating the tasks, the focus team proactively claimed space in the greenhouse for conducting their experiment.

In another example the three girls and one boy on team three appeared to arrive at early consensus on selecting their question, "Are cigarettes and tobacco poisonous to us?" All the members of team three helped gather information and collect data. Eventually, this team gathered information from numerous sources and spent considerable time struggling with designing an investigation. Their dilemma revolved around their increasing evidence from secondary sources that smoking was even more hazardous than they had first believed. Exposing even plants to smoke from cigarettes might be hazardous to the team members, depending on their experimental design. After the eighth week, the group leader helped the group to design surveys to examine several factors, including amount and kind of cigarettes, and length of time of smoking. The team surveyed over 100 people and debated how to interpret the survey data. They spent time after school and at lunch going through the surveys. They sustained their investment in the investigation, and their interest in finding more information increased over time.

Student dialogue centered on procedural aspects of the activity when completing teacher-designed activities. When students worked in their groups on teacher developed laboratory activities that were presented in detailed form, student discussions centered on 
how to follow the procedures in the activity. The change in dialogue to more collaborative interactions occurred when activities were more student-centered. In the initial lessons, dialogue in the group centered mainly on following the procedures in lab activities rather than higher order thinking. Students had difficulty early in the project negotiating understandings with their team members. As well as focusing on procedural aspects of the activity, some of the students appeared to lack the social skills or the motivation to cooperate with their colleagues in the group. Often there were disagreements among group members regarding roles for completing tasks.

An example of student conversation that focused on roles and how to carry out the procedures of the activity occurred during a chromatography lab. As the members of the focus team set up their chromatograms, they argued about the correct amount of water to add to the cup. Eileen told Tammy to "label the stuff," but Tammy countered that she was doing the experiment sketched on the blackboard, and did not need to label the cups. In other groups some of the students engaged in recording their data silently, without sharing their results with their team members.

In contrast to talk focused on procedures, in week 7 members of the focus team engaged in a lively exchange of ideas about which vitamins might be the most hazardous and how they might set up an investigation. Eileen suggested that they give vitamins to plants as an alternative to the team's first ideas of giving vitamins to humans. Bobby was concerned about the validity of using plants for their experiment on human vitamin supplements. Each student actively participated in the discourse, and even brought the teacher into their discussion, humorously suggesting that she be a test case.

The focus team initially planned to germinate seeds. However, the team members ran out of time and decided to start with plants purchased from a greenhouse. After the team had finalized its experimental design, further negotiation centered on how to collect the data. For example, the focus team debated about what kinds of plants to use, how to administer the vitamins that were in capsule form to the plants, and how to measure the change in the plants. During the discussion about their vitamins investigation, the members of the focus team listened to the other members' ideas. Team members often disagreed, but eventually reached a consensus.

When public sharing centered on discussions of their own experiences, students were more cognitively engaged. Public sharing in this study refers to whole-class discussions of science concepts and issues initiated by the teacher or the students. This more structured setting contrasts with the informal conversations that occurred at the team tables or between pairs of students. Instances of public sharing in which students' cognitive engagement was low were characterized by students responding to the teacher's questions in the classic IRE pattern: initiation of a teacher question; reply by the student; and then evaluation of the student's response by the teacher (Mehan, 1986). During this traditional public sharing, student participation was generally limited to answering the teacher's questions relating to science concepts. In contrast, when the topic of discussion focused on real-world issues or events that related to the students' lives, the nature of the public sharing changed. This change was evidenced by increased interactions and students volunteering to share ideas.

There were many examples in which students related the topic of discussion to their own experiences. An example late in the second week of a public sharing session involved students debating important issues and relating these issues to science concepts. A chemical tanker had overturned on the exit ramp of the expressway within two miles of the school. The event trapped a school bus in a traffic jam along with parents returning home from work and bringing students home from school. The students on the bus were forced to evacuate and walk the rest of the way home. The next day several students ran into class talking about the spill. 
During class discussions of the spill the students recounted the accident and evaluated the impact on the community. Most of the students had some personal connection with the problem of the chemical spill. Many of the students had been on the school bus or their parents had been affected on their way home from work. Other students lived in the neighborhood or frequented several restaurants near the spill. Some of the students saw the temporarily closed signs on the restaurants warning customers of possible contaminated water. Other students heard the local news shows and knew of people who were directly involved. The students actively engaged in reconstructing the series of events and attempted to assess the impact of these events on the environment. As soon as one student finished talking, another one would offer information. This engagement contrasted sharply with the passive response of the students in the previous discussions relating to uncontexualized science topics such as chemical and physical changes.

Public sharing became important as the team projects progressed. During a whole-class session during week 5, team two described the design of their experiment. Denny told the class that his father was in construction, and his team could get a lot of asbestos by peeling it off from old pipes. His team members could then apply this asbestos to plants. Some of the students questioned the safety of this, and even the videotaper became alarmed at the potential hazard. Some students suggested that perhaps they should reconsider this design of their investigation. After receiving this feedback, team two eventually redesigned their experiment. Team members changed their focus from applying asbestos to plants, to studying the $\mathrm{x}$-rays of lungs of patients who had been exposed to asbestos.

The involvement of students in this developing classroom community was evident when the seven teams began giving their final presentations to the class. For these final presentations, the teams shared their findings much like a scholarly meeting of a group of scientists. Each of the three to four members of the teams participated in sharing different aspects of the team's findings. In this middle school science classroom, the sharing consisted of less sophisticated levels of knowledge than would be found in real scientific research conferences. However, the respect shown to their peers paralleled that shown in adult communities. The members of the classroom exemplified a community in which the members are granted the authority of knowing.

Interactions with outside resource people increased students' investment in the project. Collaboration with experts outside the classroom did not occur extensively during this project. During the early weeks, there were no collaborative interactions with experts. However, when interactions with experts occurred, the association with the expert had an important impact on the team's progress. The variety of outside resources used by the students during the project ranged from nationwide e-mail correspondence to personal contacts with people in the school community, such as parents of the team members, university students, the school librarian, and even the school custodian.

The influence of experts linked by telecommunications began during the third week of the project, and continued after the project had officially ended. The teacher helped the students access an electronic bulletin board called LabNet, an area on America OnLine. This bulletin board, developed by the Technical Education Research Center, is staffed by scientists and educators and is used by teachers of other project-based classrooms (Roup et al., 1993). The original LabNet project was aimed at high school physics teachers to support them in using project-enhanced learning. In this study the teacher extended the use of LabNet by having the students post their own inquiries. Through the use of the LabNet bulletin board, many of the teams used their e-mail responses to add to their knowledge base of their poison, or to refine their experiments.

The teams were excited when they received responses to their messages. The students viewed the responses as important sources of information, and several of the students 
asked to come in at lunch time and after school to use the electronic bulletin board. Some of the e-mail messages contained suggestions for alternative ways to collect data. An example of a student who recognized the importance of using telecommunications was Bobby. Before the project, Bobby's mother had requested a teacher conference because of his indifference to school. As the project progressed, Bobby became proficient as the e-mail operator and took ownership in posting the team word-processed letters and downloading responses. Bobby took on a new role of computer expert in the classroom.

In addition to the e-mail connection, students made personal contacts with resource people outside the classroom who influenced their investigations. Two of the teams established contact with the school custodian. Members of team four studying chlorine initiated support from the custodian to conduct tests of chlorine levels in the school pool and other water samples that the team had selected. Team six also collaborated with the custodian. While they were collecting radon data using e-perm detectors, the students discovered drums of acids stored in the school's basement, which promoted further inquiry.

Besides school-based contacts, parents served as experts. A father of one of the members of team two became an important adjunct in their investigation of asbestos and their final team presentation. The design of their investigation changed as a result of this collaboration, which occurred unexpectedly. During a parent conference late in the spring, Linda's mother related this story of her daughter's collaboration with her father. At dinner one night, Linda brought up the dilemma of her team's concern with working with asbestos. Her team wanted to conduct an experiment testing the effects of asbestos on plants. Yet, during a whole-class session, several members of the class had pointed out safety issues with their plan. Linda told her father that they needed a resource person; they needed a scientist. As Linda continued to explain her team's project, her dad said, "Hey, I'm a scientist." Linda expressed her disbelief. Her dad assured her that, as a radiologist, he was really a scientist, and maybe he could help. Linda's father suggested the idea that the team eventually adopted: that they could look at x-rays of people's lungs who had been exposed to asbestos and those who had not been exposed, and then compare them. Eventually team two integrated Linda's father into part of their final presentation as an expert scientist.

When students worked in teams answering their own questions, students took responsibility for learning and teaching. During the first few weeks of the project, the students did not take on additional responsibility for their own learning, other than to complete teacher-designed activities. For example, in reviewing physical and chemical changes of matter using a videolaser-disk program, students appeared passive. Some of the students, but not all, took notes on teacher-designed worksheets. Few of the students asked their own questions or demonstrated a sense of responsibility for their own learning.

When students were given responsibility for choosing and carrying out their investigations, there was evidence that the role of student and teacher was interchanged as students shared their knowledge with other team members and with the class. When working on their team projects, individual students demonstrated a responsibility for their own learning. This contrasted with earlier activities that focused on learning science concepts related to topics found in the textbook during which students performed activities to the extent required by the teacher. Evidence of taking responsibility for learning and teaching was in the students initiating their own questions and following through on conducting their team investigations.

Examples of incidents in which students began taking responsibility for their own learning increased during the course of the instruction. One example of students taking increased responsibility was team six, studying radon. While looking for information in the media center, this team expressed concern that they might not be able to gather actual data. The study of radon was particularly relevant to two of the team members due to recent detection 
of high radon levels in their neighborhood. One of the students shared expertise gained from having his own home tested for radon by a commercial testing company. Eventually this team acquired the use of a radon tester, and surveyed the school for evidence of unsafe levels of radon.

As the project evolved and each team embraced their particular poison, team members became motivated to share their findings with other teams. For example, students in team three frequently volunteered to share information on smoking and tobacco. The members of this group formed a cohesive unit early in the instruction. As they investigated the hazards of smoking and began to gather data, members enthusiastically shared preliminary findings with the teacher and other members of the class.

\section{CONCLUSIONS AND DISCUSSION}

The intent of this study was to explore the theoretical dimensions of a community of learners in the context of practice. Unlike other studies that focused on specific aspects of collaboration (e.g., Cohen, 1986), on mathematics classrooms (Ball, 1990; Lampert, 1990; Wood, Cobb, \& Yackel, 1992) and on students working in groups on focused problems using computer probes (Linn \& Songer, 1991), this study focused on the student-student and student-teacher interactions within the complexity of an eighth grade science classroom. The findings of this study point to three important factors that influenced the learning community in this middle school classroom: (1) the importance of the driving question in contributing to the authentic nature of the investigations; (2) the importance of the teacher's role in supporting students in collaborating with peers and people outside the classroom, and (3) the extended time required for teams to develop collaborative relationships.

First, the findings suggest that the authenticity of the tasks fostered students' collaboration when exploring questions and conducting investigations of their own design. As stated earlier, the authors use the term "authentic" to include both the kinds of problems that resemble those which scientists might encounter and those that would be meaningful to children - in this case, eighth grade students.

Analysis of the data suggests that tasks early in the project were not authentic and did not thoughtfully engage most of the students. A superficial look at the activity level of the students working in their groups might lead an observer to conclude that the students were cognitively engaged and thoughtful in their dialogue. However, analyses of videotaped student conversations revealed students completing only those tasks delegated to them by assigned roles and talk centered on such procedural aspects as carrying out the tasks and manipulating materials. Counterproductive behaviors exhibited by some students in their groups were found in other studies (Hogan, 1998).

Movement toward collaboration occurred after introduction of the driving question several weeks after the start of the instruction on chemical substances. The importance of the driving question as a way to embed tasks in real-world issues relates to Tinker's (1991) ideas of project-based, authentic instruction. The broad nature of the driving question and its potential to spawn other questions related to the subject matter of chemistry as well as to the lives of students, enabled students to ask their own authentic questions. An important point here in comparing nonauthentic tasks and authentic tasks is that in planning the poisons project, the teacher intended that all tasks would be authentic, similar to models of open inquiry (Roth, 1995) and situated learning (Lave, 1988). For example, early in the project, the teacher designed activities intended to engage the students in components of inquiry. Selection of activities was based on careful consideration of purpose, her vision of the project, and the capabilities of the students (Roup et al., 1993). In retrospect, these 
activities did not engage students in the kinds of discussions about scientific inquiry and subject matter consistent with the national standards (AAAS, 1993; NRC, 1996). This issue of authenticity of tasks raises questions about the extent to which investigations centering on narrow, content-bound topics, such as of the thermal expansion of solids and specific heat of metals, promote collaboration (Roth, 1994). Other reports of classrooms in which students work together on open-ended investigations have not elaborated on the details of the processes involved in establishing these kinds of learning environments. Interactions that occurred as students attempted to solve problems in this study are not readily apparent in other reports (Linn \& Songer, 1992; Roth, 1994; Roup et al., 1993).

Second, the teacher played a central role in facilitating collaboration in this study. In this middle school classroom, the teacher's sensitivity to the amount of direction students needed appeared critical in helping students acquire interdependency in their groups and taking responsibility for their own learning. Although too much teacher direction deterred collaboration, too little guidance also stalled the students' progress in designing and carrying out investigations. The teacher had anticipated that high-achieving students would be able to move their teams toward producing the final group product without explicit directions. When the teacher decided to communicate more explicit expectations, group productivity increased. One example of teacher guidance that proved important in this study was a handout detailing the poisons project timelines and the teacher's expectations for group and individual products. The handout appeared to shift groups towards increased interdependency (see Crawford, 1996, p. 98). The students' need for detailed descriptions of final products was found by other researchers (Roth, 1994; Roth \& Roychoudhury, 1993a; Roup et al., 1993).

It was also important to let groups make decisions on their own in order to avoid undermining the group's reliance on their team members. The teacher's encouragement of students to take on responsibility by increasing the group's decisionmaking is consistent with Cohen's (1986) argument that groups must be delegated authority by the teacher. Knowing when to give support to students and when to leave students on their own, demands continuous assessment of group productivity. The importance of giving students opportunity to design their own investigations was evidenced by the increased involvement of the students as their teams pursued solutions to their team questions. This finding agrees with Brown's notion that teachers need to "serve as active role models of learning and as responsive guides to students' discovery processes" (Brown, 1992, p. 150). The varied roles of the teacher are alluded to in the standards, "At all stages of inquiry, teachers guide, focus, challenge, and encourage student learning" (NRC, 1996, p. 33). Common descriptors of roles for teachers using constructivist and inquiry-oriented approaches include "teacher as facilitator" and "teacher as guide." However, this study suggests that teachers need to take on more expansive roles such as mediator, diagnostician, modeler, and collaborator. The need for teachers to take on complex and changing roles has been examined in other reports (Crawford, 1998; Osbourne \& Freyberg, 1983). This raises the question of how teachers might embrace these new roles. The varied roles taken by the teacher need further study.

Third, the issue of substantial time required for establishing collaborative relationships may seem a trivial point. Yet, in this study it took groups up to 8 weeks to become fully productive in working together toward a group goal. This teacher had the benefit of substantial teaching experience, extensive science background, experience in designing investigations in research settings, and the added benefit of having these students for a period of almost 2 years. In addition, this teacher had the opportunity to collaborate about planning and instruction. Still, it took 4 additional weeks beyond the planned 8 weeks for students to develop expertise, develop productive collaborative relationships with team members, and gain closure to their investigations. 


\section{SUMMARY AND IMPLICATIONS}

A targeted outcome of this study involved documenting the importance of theoretical dimensions of a community of learners by systematically studying the student-student and student-teacher interactions over a substantial period of time. Reforms that advocate contexualizing content and engaging students in exploring questions in collaborative settings (NRC, 1996) necessitate exploring the processes of establishing communities of learners. Few studies have looked at the broad spectrum of dimensions of a community of learners developed from the literature, and specifically science classrooms.

Careful analyses of student and teacher interactions underscored the impact of three of the literature-based components: authenticity of the tasks; interdependency in small group work; and interchanging the teacher and student roles. The increased engagement of students in this study as they made decisions and grappled with designing investigations reinforces other studies describing the power of question-driven instruction (Roth, 1995; Roth \& Roychoudhury, 1993a; Roup et al., 1993; Warren, Rosebery, \& Conant, 1989). By the end of the study students demonstrated, to a large extent, an understanding of the various ways to carry out scientific investigations and some of the issues in designing investigations, and collecting and interpreting data. This study highlights the importance of allowing students to choose their own questions to explore, that when coupled with opportunity to exchange ideas and substantial teacher support, enhances the collaborative aspects of the classroom.

On the less positive side, this study raises questions about the likelihood that novice teachers will have the tools necessary to successfully establish the kind of learning community described in this study. Examples of students forming a community by sharing responsibility for their own learning have been reported in studies involving preservice math teachers (Wilcox et al., 1991). Yet, these same preservice teachers reported that they had difficulty guiding students in their own classrooms to take on this same responsibility. A productive line of research might involve examining the difficulties less experienced teachers encounter during transformation of roles of teacher and students as they strive to create communities of learners in their own classrooms.

\section{REFERENCES}

American Association for the Advancement of Science (1993). Benchmarks for science literacy. New York: Oxford University Press.

Ball, D. L. (1990). With an eye on the mathematical horizon: Dilemmas of teaching elementary school mathematics. (Craft Paper No. 90-3). East Lansing, MI: National Center for Research on Teacher Education.

Blumenfeld, P., Soloway, E., Marx, R., Krajcik, J., Guzdial, M., \& Palincsar, A. (1991). Motivating project-based learning: Sustaining the doing, supporting the learning. Educational Psychologist, 26, 369-398.

Brown, A. L. (1992). Design experiments: Theoretical and methodological challenges in creating complex interventions in classroom settings. Journal of the Learning Sciences, 2, 141-178.

Brown, A. L., \& Campione, J. C. (1990). Communities of learning and thinking, or a context by any other name. In D. Kuhn (Ed.), Contributions to Human Development, 21, 108-125.

Brown, J. S., Collins, A., \& Duguid, P. (1989). Situated cognition and the culture of learning. Educational Researcher, 18, 32-42.

Bruffee, K. (1993). Collaborative learning. Baltimore, MD: The Johns Hopkins University Press.

Cognition and Technology Group at Vanderbilt (1990). Anchored instruction and its relationship to situated cognition. Educational Researcher, 19, 2-10.

Cohen, E. (1986). Designing groupwork: Strategies for the heterogeneous classroom. New York: Teachers College Press. 
Collins, A., Brown, J. S., \& Newman, S. (1989). Cognitive apprenticeship: Teaching the crafts of reading, writing, and mathematics. In L. Resnick. (Ed.), Knowing, learning, and instruction (pp. 453-494). Hillsdale, NJ: Erlbaum.

Crawford, B. A. (1996). Examining the essential elements of a community of learners in a middle grade science classroom. Doctoral dissertation, University of Michigan. Dissertation Abstracts International, 57 (No. 9624591).

Crawford, B. A. (1998, April). Creating and sustaining an inquiry-based classroom: A different view of teacher's work. Paper presented at the annual conference of the National Association of Research in Science Teaching, San Diego, CA.

Dewey, J. (1938). The school and society. In M. Dworkin (Ed.), Dewey on education. New York: Teachers College Press.

Driver, R., Asoko, H., Leach, J., Mortimer, E., \& Scott, P. (1994). Constructing scientific knowledge in the classroom. Educational Researcher, 23, 4.

Duschl, R., \& Gitomer, D. (1993, April). Emergent conversations about portfolio assessment. Paper presented the annual meeting of the American Educational Research Association, Atlanta, GA.

Gallagher, J. (1989). Research on secondary school science practices, knowledge, and beliefs: A basis for restructuring. In M. Matyas, K. Tobin, \& B. Fraser (Eds.), Looking into windows: Qualitative research in science education. Washington, DC: American Association for the Advancement of Science.

Hogan, K. (1998, April). Sociocognitive roles in science group discourse. Paper presented at the annual conference of the National Association of Research in Science Teaching, San Diego, CA.

Johnson, D., \& Johnson, R. (1991). So what's new about cooperative learning in science? Cooperative Learning, 11, 2-3.

Keys, C. (1993). The intervention between a collaborative writing intervention and the development of science understandings in a ninth-grade classroom. Unpublished doctoral dissertation, University of Michigan, Ann Arbor, MI.

Krajcik, J., Blumenfeld, P., Marx, R., \& Soloway, E. (1994). A collaborative model for helping middle grade teachers learn project-based instruction. Elementary Science Journal, 94, 483-498.

Lampert, M. (1990). When the problem is not the question and the solution is not the answer: Mathematical knowing and teaching. American Educational Research Journal, 27, 29-63.

Lave, J. (1988). Cognition in practice: Mind, mathematics, and culture in everyday life. Cambridge, UK: Cambridge University Press.

Lave, J., \& Wenger, E. (1991). Situated learning: Legitimate peripheral participation. Cambridge, UK: Cambridge University Press.

Linn, M., \& Burbules, N. (1993). Construction of knowledge and group learning. In K. Tobin (Ed.), The practice of constructivism in science education. Washington, DC: AAAS.

Linn, M., \& Songer, N. (1991). Teaching thermodynamics to middle school students: What are appropriate cognitive demands? Journal of Research in Science Teaching, 28, 885-918.

Magnusson, S., \& Palincsar, A. (1995). Learning environments as a site of science education reform: An illustration using interdisciplinary guided inquiry. Theory into Practice, 34, 43-50.

Marx, R., Blumenfeld, P., Krajcik, J., Blunk, M., Crawford, B., Kelly, B., \& Meyer, K. (1994). Enacting project-based science: Experiences of four middle grade teachers. Elementary School Journal, 94, 517-538.

McCaslin, M., Tuck, D., Wiard, A., Brown, B., LaPage, J., \& Pyle, J. (1994). Gender composition and small group learning in fourth-grade mathematics. Elementary School Journal, 94, 467-482.

Mehan, H. (1986). "What time is it Denise?": Asking known information questions in classroom discourse. In M. Hammersley (Ed.), Case studies in classroom research. Milton Keynes, UK: Open University Press.

Miles, M., \& Huberman, A. M. (1994). Qualitative data analysis: An expanded sourcebook, 2nd ed. Beverly Hills, CA: Sage.

National Research Council (1996). National science education standards. Washington, DC: National Academy Press.

Newman, D., Griffin, P., \& Cole, M. (1989). The construction zone: Working for cognitive change in school. Cambridge, UK: Cambridge University Press. 
Osbourne, R., \& Freyberg, M. (1985). Roles for the science teacher. In: Learning in science. The implications of children's science. Auckland: Heinemann. (pp. 91-99).

Resnick, L. B. (1987). Learning in school and out. Educational Researcher, 16, 13-20.

Rogoff, B. (1990). Apprenticeship in thinking: Cognitive development in social context. Oxford, UK: Oxford University Press.

Rogoff, B. (1994). Developing understanding of the idea of communities of learners. Mind, Culture, and Activity, 4, 209-229.

Roth, W.-M. (1994). Experimenting in a constructivist high school physics laboratory. Journal of Research in Science Teaching, 31, 197-223.

Roth, W.-M. (1995). Authentic school science. Dordrecht: Kluwer.

Roth, W.-M., \& Roychoudhury, A. (1993a). The development of science process skills in authentic contexts. Journal of Research in Science Teaching, 30, 127-152.

Roth, W.-M., \& Roychoudhury, A. (1993b). The concept map as a tool for the collaborative construction of knowledge: A microanalysis of high school physics students. Journal of Research in Science Teaching, 30, 503-534.

Roup, R., Gal, S., Drayton, B., \& Pfister, M. (Eds.) (1993). LabNet: Toward a community of practice. Hillsdale, NJ: Lawrence Erlbaum.

Schwab, J. (1976). Education and the state: Learning community. In The great ideas today. Chicago: Encyclopedia Britannica.

Scott, C. (1994). Project-based science: Reflections of a middle school teacher. Elementary School Journal, 95, 75-94.

Sharan, S., \& Hertz-Lazarowitz, R. (1980). A group investigation method of cooperative learning in the classroom. In S. Sharan, A. P. Hare, C. Webb, \& R. Hertz-Lazarowitz (Eds.), Contributions to the study of cooperation in education (pp. 19-46). Provo, UT: Brigham Young University Press.

Slavin, R. E. (1981). Synthesis of research on cooperative learning. Educational Researcher, 655659.

Solomon, J. (1989). The social construction of school science. In R. Millar (Ed.), Doing science. London: Falmer Press.

Smith, E. (1991). A conceptual change model of learning science. In S. Glynn, G. Yeany, \& B. Britton (Eds.), The psychology of learning science. Hillsdale, NJ: Lawrence Erlbaum.

Tinker, R. (1991). Thinking about science. Unpublished manuscript. Cambridge, MA: Technical Educational Research Center.

Tobin, K., \& Gallagher, J. (1987). What happens in high school science classrooms? Journal of Curriculum Studies, 19, 549-560.

Vygotsky, L. S. (1978). Mind in society: The development of higher psychological processes (M. Cole, V. John-Steiner, S. Scriber, \& E. Souberman, Eds. and trans.). Cambridge, MA: Harvard University Press.

Warren, B., Rosebery, A., \& Conant, F. (1989). Cheche konnen: Science literacy in language minority classrooms. Paper presented at the First Innovative Approaches Research Project Symposium, Washington, DC.

Wilcox, S., Schram, P., Lappan, G., \& Lanier, P. (1991). The role of a learning community in changing preservice teachers' knowledge and beliefs about mathematics education. (Craft Paper 91-4). East Lansing, MI: Michigan State University, National Center for Research on Teacher Education.

Wood, T., Cobb, P., \& Yackel, E. (1992). Change in learning mathematics: Change in teaching mathematics. In H. Marshall (Ed.), Redefining student learning. Norwood, NJ: Ablex.

Yin, R. (1989). Case study research: Design and methods. Newbury Park, CA: Sage Publications. 